\title{
Cytogenetic and molecular markers reveal the complexity of the genus Piabina Reinhardt, 1867 (Characiformes: Characidae)
}

\author{
Marlon Felix Pazian, Luiz Henrique Garcia Pereira, Cristiane Kioko Shimabukuru-Dias, \\ Claudio Oliveira and Fausto Foresti
}

\begin{abstract}
Cytogenetic and molecular analyses were carried out in fish representative of the genus Piabina. This study specifically involved the species P. argentea and P. anhembi collected from areas of the Paranapanema and Tietê River basins, Brazil. Our findings suggest that fish classified as Piabina argentea in the Paranapanema and Tietê Rivers may represent more than one species. The samples analyzed differed by cytogenetic particularities and molecular analyses using partial sequences of the genes $\mathrm{COI}$ and $\mathrm{CytB}$ as genetic markers revealed three distinct groups of $P$. argentea with genetic distances sufficient to support the conclusion that the three samples analyzed are three distinct taxonomic units.

Foram realizadas análises citogenéticas e moleculares em representantes do gênero Piabina. O estudo envolveu especificamente as espécies $P$. argentea e $P$. anhembi coletadas nas áreas das bacias hidrográficas dos rios Paranapanema e Tietê (Brasil). Os dados sugerem que a espécie $P$. argentea coletada nas bacias dos rios Paranapanema e Tietê podem representar mais de uma espécie. As amostras analisadas diferem por particularidades citogenéticas e nas análises moleculares utilizando-se sequências parciais dos genes COI e CytB, revelando três grupos distintos de $P$. argentea com distâncias genéticas suficientes para sustentar a conclusão de que as três amostras analisadas são unidades taxonômicas distintas.
\end{abstract}

Key words: DNA Barcoding, Freshwater fishes, Fish, mtDNA, 18S rDNA, 5S rDNA.

\section{Introduction}

The Neotropical freshwater fish fauna is considered the richest in the world (Schaefer, 1998). According to Reis et al. (2003), approximately 6,000 freshwater fish species are estimated to be found in this region, 4,475 of these species are considered valid and approximately 1,550 are recognized but not described.

Cytogenetic fish data are available for 475 species of Characiformes, 318 species of Siluriformes, 48 species of Gymnotiformes and 199 freshwater species belonging to the superorder Ostariophysi (Oliveira et al., 2009). According to Almeida-Toledo et al. (2000), the chromosome number among the Neotropical fish species studied ranges from 20 in Pterolebias longipinnis (Garman, 1895) (Oliveira et al., 1988) to 134 in Corydoras aeneus (Gill, 1858) (Turner et al., 1992). In some groups the number and morphological features of the chromosomes are conserved while in other freshwater fish groups these characteristics show remarkable variation.

Cytogenetic techniques have been used to characterize populations, species, genera and families, and many of them have proved to be efficient markers in identifying intra and inter-specific chromosome variations (Mantovani et al., 2000). The development of specific cytogenetic techniques, mainly conventional chromosome banding techniques, has facilitated accurate chromosome identification and permitted a better understanding of the karyotypic structure. These findings have revealed relationships among species and the mechanisms involved in the evolutionary processes that have occurred in this group of organisms (Almeida-Toledo et al., 2000). Recently, the studies in chromosome structure were challenged with the introduction of new molecular cytogenetic techniques that make it possible to analyze specific parts of the chromosomes by using microdissection procedures and in situ hybridization with localized genomic probes (Pansonato-Alves et al., 2011).

The first cytogenetic studies on the species Piabina argentea (Reinhardt, 1867) were carried out with specimens from the Mogi-Guaçu River (São Paulo, Brazil). This sample has a $2 \mathrm{n}=52$ chromosomes $(26 \mathrm{~m} / \mathrm{sm}+26 \mathrm{st} / \mathrm{a})$ (Portela et al., 1988) with NORs located in multiple sites in the terminal region of the chromosomes. However, Peres et al. (2007) also found specimens of $P$. argentea from the São Francisco river basin with a $2 \mathrm{n}=52$ chromosomes $(8 \mathrm{M}+14 \mathrm{SM}+16 \mathrm{ST}+14 \mathrm{~A})$ and the NORs located in the terminal region of only one chromosome pair.

Universidade Estadual Paulista “Júlio de Mesquita Filho” (UNESP), Laboratório de Biologia e Genética de Peixes, Instituto de Biociências, 18.618-000 Botucatu, SP, Brazil. pazian@ibb.unesp.br (MFP) 
The use of molecular markers in taxonomy has enabled breakthroughs in this area of research and has enabled the identification of species with the use of genes or specific genomic segments. Following these trends, Hebert et al. (2003) proposed a molecular system of identification of species called DNA barcoding, which is based on using a fragment of the Cytochrome Oxidase I (COI) mitochondrial gene. Many studies have shown the efficacy of this method in identifying many fish species (Valdez-Moreno et al., 2009; Ward , 2009; Lara et al., 2010; Pereira et al., 2011). Some of these findings have resulted in the proposal of new species of fish (Ward et al., 2008; Nguyen \& Seifert, 2008; Yassin et al., 2008).

Considering the wide distribution of $P$. argentea and the endemic distribution of $P$. anhembi da Silva \& Kaefer, 2003, as well as the small number of cytogenetic studies for this group, the aim of this study was to characterize different populations of $P$. argentea and $P$. anhembi using cytogenetic markers (Giemsa, C-banding and Ag-NORs) and molecularcytogenetic markers (FISH using probes for the ribosomal genes $5 \mathrm{~S}$ rDNA and 18S rDNA) and thereby contribute new information about the karyotype of these species. Additionally, in order to verify the species status of the widely distributed $P$. argentea, we assessed partial sequences of the $\mathrm{COI}$ and Cytochrome $\mathrm{B}(\mathrm{CytB})$ mitochondrial genes using the parameters proposed by the DNA barcoding technique. Molecular analysis combined with cytogenetic data should provide information that is relevant to establishing an accurate species status for this fish group.

\section{Material and Methods}

We analyzed forty-five specimens of the fish species $P$. argentea (22 males and 23 females) from the Paranapanema river (one local sample) and the Tietê river (two local samples) and 13 specimens of $P$. anhembi (upper Tietê River basin) located in São Paulo State, Brazil (Table 1; Fig. 1). These samples were collected from 2006 to 2008. After the samples were processed for chromosome preparation, the specimens were fixed in $10 \%$ formalin, preserved in $70 \%$ alcohol, identified and deposited in the fish collection of the Laboratório de Biologia e Genética de Peixes (LBP), UNESP, Botucatu (São Paulo State, Brazil) (collection numbers LBP $6743,6744,6745,6742$, and 4622). Small fragments of muscle or fin were collected and preserved in $95 \%$ ethanol for molecular analysis.

\section{Cytogenetic analysis}

Mitotic chromosome preparations were obtained from kidney and gill fragments following the technique used by Foresti et al. (1981). NOR sites were identified by silver nitrate following the technique proposed by Howell \& Black (1980), and C-banding was performed following the protocol described by Sumner (1972).

Fluorescent in situ hybridization (FISH) was conducted to locate the rDNA sites on chromosomes. The 18S probe and $5 \mathrm{~S}$ probe were generated following the protocol described by Pinkel et al. (1986) with 77\% of stringency. The $18 \mathrm{~S}$ probe was obtained from Prochilodus argenteus (Agassiz, 1829) following the protocol described by Hatanaka \& Galetti (2004), and the 5S rDNA probe was obtained from Leporinus elongatus (Valenciennes, 1850) (Martins \& Galetti , 1999). 18S rDNA and 5S rDNA probes were labeled with Biotin 14dATP by nick translation following the manufacturer's instructions (Bionick Labeling System - Invitrogen). Additionally, 18S rDNA and 5S rDNA probes were also labeled with Digoxigenin 11-dUTP (Roche Applied Science) via PCR (Polymerase Chain Reaction). The hybridization signals were detected using anti-digoxigenin-rhodamine and conjugated avidin-fluorescein (FITC). Hybridization signals were amplified with biotinylated anti-avidin antibodies. The metaphasic chromosomes were treated using methods described by Pinkel et al. (1986), counterstained with DAPI and analyzed under optical photomicroscope (Olympus $\mathrm{BX61)}$. The metaphase figures were captured using the software Image Pro Plus 6.0 (MediaCybernetics).

Chromosome morphology was determined according to the arm ratio proposed by Levan et al. (1964). The chromosomes were classified as metacentric (m), submetacentric (sm), subtelocentric (st) and acrocentric (a) and were organized in decreasing size in the karyotypes.

\section{Molecular analysis}

Total genomic DNA was isolated from the fin or muscle tissue of each specimen using the DNeasy Tissue Kit (Qiagen) according to the manufacturer's instructions. The partial mitochondrial Cytochrome C Oxidase subunit I gene (COI $\sim 648 \mathrm{pb}$ ) was amplified by polymerase chain reaction (PCR) using two sets of primers: FishF1 5'TCAACCAACCACAAAGACATTGGCAC3'; FishF2 5'TCGACTAATCATAAAGATATCGGCAC3'; FishR1 5'TAGACTTCTGGGTGGCCAAAGAATCA3' and FishR2 -

Table 1. Cytogenetic data available for species of the genus Piabina. References: 1 - Portella et al. (1988); 2 - Peres et al. (2007); 3 - present study; (SP) São Paulo State; (MG) Minas Gerais State.

\begin{tabular}{|c|c|c|c|c|c|c|}
\hline Species & Locality & Karyotype & $2 n$ & FN & NORs & Ref. \\
\hline$\overline{\text { Piabina argentea }}$ & Mogi Guaçu (SP) & $26 \mathrm{~m} / \mathrm{sm}+26 \mathrm{st} / \mathrm{a}$ & 52 & - & 06 & 1 \\
\hline Piabina argentea & São Francisco (MG) & $08 m+14 s m+16 s t+14 a$ & 52 & 90 & 02 & 2 \\
\hline Piabina argentea & Itatinga (SP) & $04 m+22 s m+10 s+16 a$ & 52 & 88 & 02 & 3 \\
\hline Piabina argentea & Botucatu (SP) & $08 m+18 s m+18 s t+10 a$ & 52 & 98 & 02 & 3 \\
\hline Piabina argentea & Bauru (SP) & $04 m+24 s m+10 s t+14 a$ & 52 & 90 & 04 & 3 \\
\hline Piabina anhembi & Salesópolis (SP) & $08 m+10 s m+16 s t+18 a$ & 52 & 86 & 02 & 3 \\
\hline
\end{tabular}




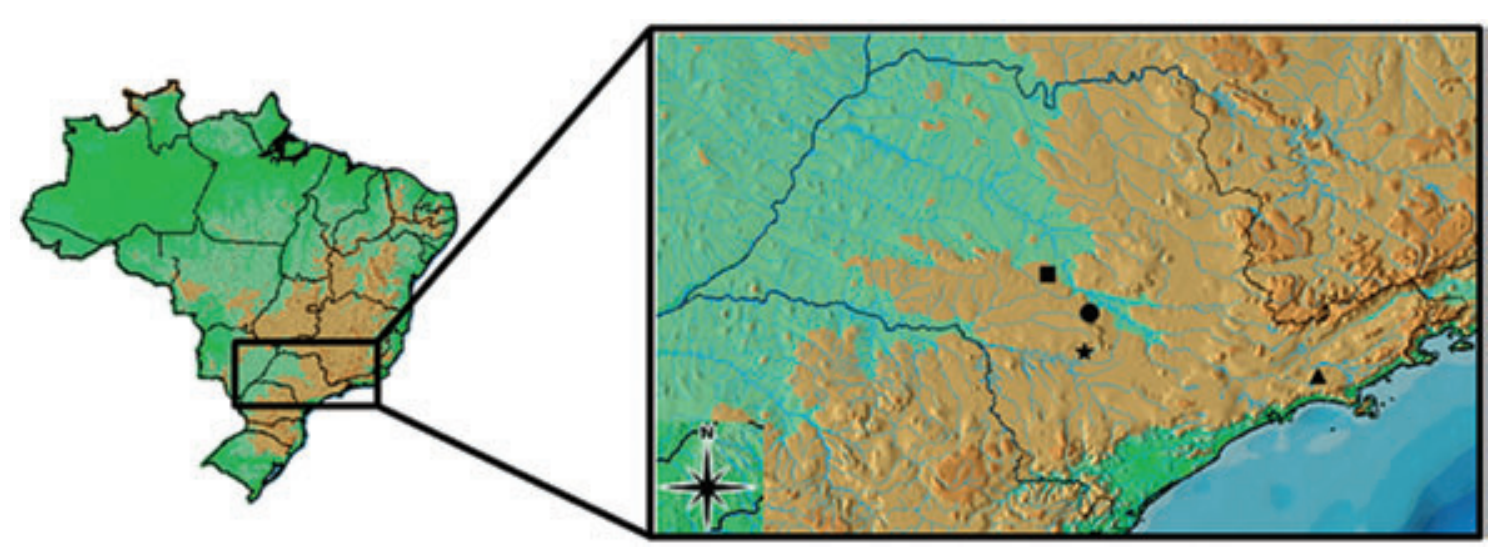

Fig. 1. Map indicating the collection points for Piabina argentea and P. anhembi, the drainage regions of the Parapanema and Tietê river basins are highlighted. Symbols correspond to fish samples from Bauru (square), Botucatu (circle), Itatinga (star), and the triangle represents the sample of $P$. anhembi from Salesópolis.

5'ACTTCAGGGTGACCGAAGAATCAGAA3' (Ward et al., 2005). The whole Cytochrome B (CytB - 1118 pb) mitochondrial gene was amplified by PCR using the primers CytB-F 5'GACTTGAAAAACCAYCGTTGT3' and CytB-R 5'GCTTTGGGAGTTAGDGGTGGGAGTTAGAATC3'.PCR was carried out on a thermocycler (Veriti ${ }^{\circledR}$ 96-Well Thermal Cycler, Applied Biosystems) in a total volume of $12.5 \mu \mathrm{l}$ containing 0.3 $\mu l$ of dNTP ( $2 \mathrm{mM}), 1.25 \mu \mathrm{l} 10 \mathrm{X}$ Taq buffer $(50 \mathrm{mM} \mathrm{KCl}, 10 \mathrm{mM}$ Tris-HCl, $0.1 \%$ TritonX-100 and $\left.1.5 \mathrm{mM} \mathrm{MgCl}_{2}\right), 0.3 \mu \mathrm{l}$ of each primer $(10 \mu \mathrm{M}), 0.7 \mu \mathrm{l}$ of $\mathrm{MgCl}_{2}(50 \mathrm{mM}), 0.05 \mu \mathrm{l}$ of Taq-Pht DNA polymerase (5 U), $1 \mu \mathrm{l}$ of template DNA (10-20 ng) and ultrapure water. The conditions of thermocycling for the COI gene included the following: an initial denaturation at $95^{\circ} \mathrm{C}$ for $5 \mathrm{~min}$; 30 cycles of denaturation at $95^{\circ} \mathrm{C}$ for 45 seconds, annealing at $54^{\circ} \mathrm{C}$ for 30 seconds and extension at $72^{\circ} \mathrm{C}$ for 60 seconds; and a final extension at $72^{\circ} \mathrm{C}$ for 10 minutes. The conditions of thermocycling for gene $\mathrm{CytB}$ included the following: an initial denaturation at $95^{\circ} \mathrm{C}$ for 5 minutes; two cycles of denaturation at $95 \mathrm{C}$ for 30 seconds, annealing at $55^{\circ} \mathrm{C}$ for 45 seconds and extension at $72^{\circ} \mathrm{C}$ for 60 seconds; 2 cycles of denaturation at $95^{\circ} \mathrm{C}$ for 30 seconds, annealing at $50^{\circ} \mathrm{C}$ for 45 seconds and extension at $72^{\circ} \mathrm{C}$ for 60 seconds; 2 cycles of denaturation at $95^{\circ} \mathrm{C}$ for 30 seconds, annealing at $48^{\circ} \mathrm{C}$ for 45 seconds and extension at $72^{\circ} \mathrm{C}$ for 60 seconds; 25 cycles of denaturation at $95^{\circ} \mathrm{C}$ for 30 seconds, annealing at $50^{\circ} \mathrm{C}$ for 45 seconds and extension at $72^{\circ} \mathrm{C}$ for 60 seconds; and a final extension at $72^{\circ} \mathrm{C}$ for five minutes.

The amplification products were verified on a $1 \%$ agarose gel stained with Loading Dye Blue Green I (LGC Biotecnologia). PCR products were purified with the enzyme-ExoSap ${ }^{\circledR}$ IT (USB Corporation) according to the manufacturer's protocol. The purified PCR product was used as a template for the PCR sequencing of both strands of DNA. The sequencing reaction was performed using the BigDye Terminator v. 3.1 Cycle Sequencing Ready Reaction kit (Applied Biosystems) in a total volume of $7 \mu \mathrm{l}$ DNA containing $1.4 \mu \mathrm{l}$ template, $0.35 \mu \mathrm{l}$ primer (10 $\mathrm{mM}), 1.05 \mu \mathrm{l}$ of $5 \mathrm{X}$ buffer, $0.7 \mu \mathrm{l}$ of BigDye mix and water. The thermal cycling conditions were an initial denaturation at $96^{\circ} \mathrm{C}$ for two minutes followed by 30 cycles of denaturation at $96^{\circ} \mathrm{C}$ for 45 seconds, annealing at $50^{\circ} \mathrm{C}$ for 60 seconds, extension at $60^{\circ} \mathrm{C}$ for four minutes. PCR products for sequencing were purified with EDTA / sodium acetate / ethanol following the protocol suggested in the BigDye Terminator Cycle Sequencing kit v.3.1 (Applied Biosystems). All of the samples were sequenced in an automatic sequencer ABI3130 Genetic Analyzer (Applied Biosystems) following the manufacturer's instructions. All of the sequences were analyzed in the program SeqScape ${ }^{\circledR}$ v2.6 (Applied Biosystems) to obtain the consensus sequences and to check for the presence of deletions, insertions and stopcodons. Sequences were aligned using the online version of the program MUSCLE (Edgar, 2004). The genetic distances between and within the clusters observed were calculated using the K2P distance model (Kimura, 1980). The neighbor-joining tree of the K2P distance was created to provide a graphic representation of the relationships among the specimens and clusters of $P$. argentea and $P$. anhembi species using the program MEGA 4.0 (Tamura et al., 2007). Bootstrap resampling (Felsenstein, 1985) was applied to assess the support for individual nodes using 1000 pseudo replicates. The sequences obtained were deposited in GenBank (accession numbers: COI - HM144047, HM144048, HM144049, HM144050, HM144091, HM144085, HM144052, HM144053, HM144086, HM144084, HM144089, HM144088, HM144094, HM144095, HM144097; CytB-GU908165, GU908166, GU908167, GU108168, GU908207, GU908201, GU908170, GU908171, GU908202, GU908200, GU908205, GU908204, GU908209, GU908210, GU908212).

\section{Results}

\section{Cytogenetic analysis}

We analyzed forty-five specimens of $P$. argentea of local samples from two tributaries of the Tietê River (Botucatu and Bauru regions) and one sample from a tributary of the Paranapanema river (Itatinga region); another sample analyzed consisted of thirteen specimens of $P$. anhembi from the upper Tietê River (Salesópolis region) (Table 1; Fig. 1). 
The analysis of 14 specimens of $P$. argentea (5 males and 9 females) from Itatinga (Table 1) with conventional Giemsa staining revealed a diploid number of $2 n=52$ $(4 m+22 s m+10 s t+16 a)$ (Fig. 2a) and a fundamental number of 88 (Table 1). Heteromorphic chromosomes were not identified in male or female karyotypes. Two subtelocentric chromosomes contained Ag-NOR marks on the terminal region of the short arms. These chromosomes are pair 18 (Fig. 2a). Fluorescent in situ hybridization (FISH) using the 18S DNA probe was consistent with the Ag-NOR marks (Fig. 3a), and the $5 \mathrm{~S}$ rDNA probe marked four sites located in the terminal region on the carrier chromosomes (Fig. 3b). Heterochromatic blocks were found in the centromeric region of multiple chromosomes and in the short arms of the second submetacentric chromosome pair (Fig. 2b).

In the sample from Botucatu, 11 specimens of $P$. argentea ( 6 females and 5 males) were analyzed (Table 1). The analysis with conventional Giemsa staining showed a diploid number of $2 \mathrm{n}=52$ $(6 m+18 s m+18 s t+10 a)($ Fig. 4a) and a fundamental number equal to 98 (Table 1). Heteromorphic chromosomes were not identified in male or female karyotypes. Silver marks on the terminal region of the short arm in two chromosomes, pair 14, were identified by the Ag-NORs technique (Fig. 4a), and fluorescent in situ hybridization using the $18 \mathrm{~S}$ rDNA probe confirmed the Ag-NORs results and two other marks were also identified (Fig. 3c). The 5S rDNA probe was located on six chromosome sites in terminal regions (Fig. 3d). Constitutive heterochromatin is restricted to the centromeric regions of most of the chromosomes (Fig. 4b).

From the Bauru location, 20 specimens of $P$. argentea (8 females and 12 males) were analyzed. The analysis with conventional Giemsa staining showed a diploid number of $2 \mathrm{n}=$ $52(4 m+24 s m+10 s t+14 a)$ and a fundamental number of 90 in specimens from this location (Table 1). Heteromorphic chromosomes were not identified in the karyotypes of males or

a
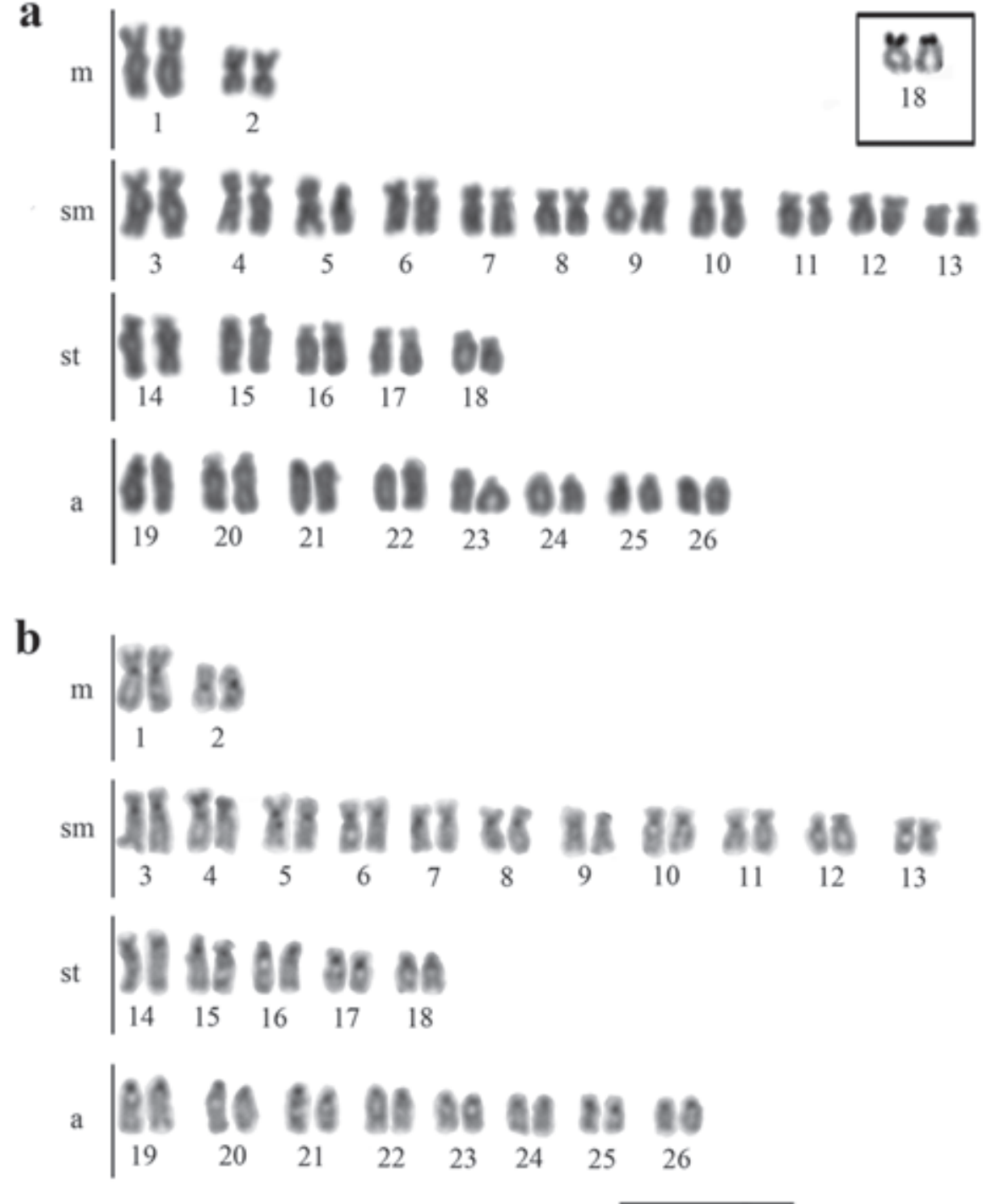

Fig. 2. Karyotype of P. argentea from Itatinga, after Giemsa staining (a) and C-banding (b) is shown. In detail, the NOR-bearing chromosomes are shown. Bar $=10 \mu \mathrm{m}$. 
females. Silver marks on the terminal region of the short arms in four submetacentric chromosomes, pairs number 3 and 17, were identified using the Ag-NORs technique (Fig. 5a), and fluorescent in situ hybridization using the 18S rDNA probe confirmed the Ag-NORs results and two other marks were also
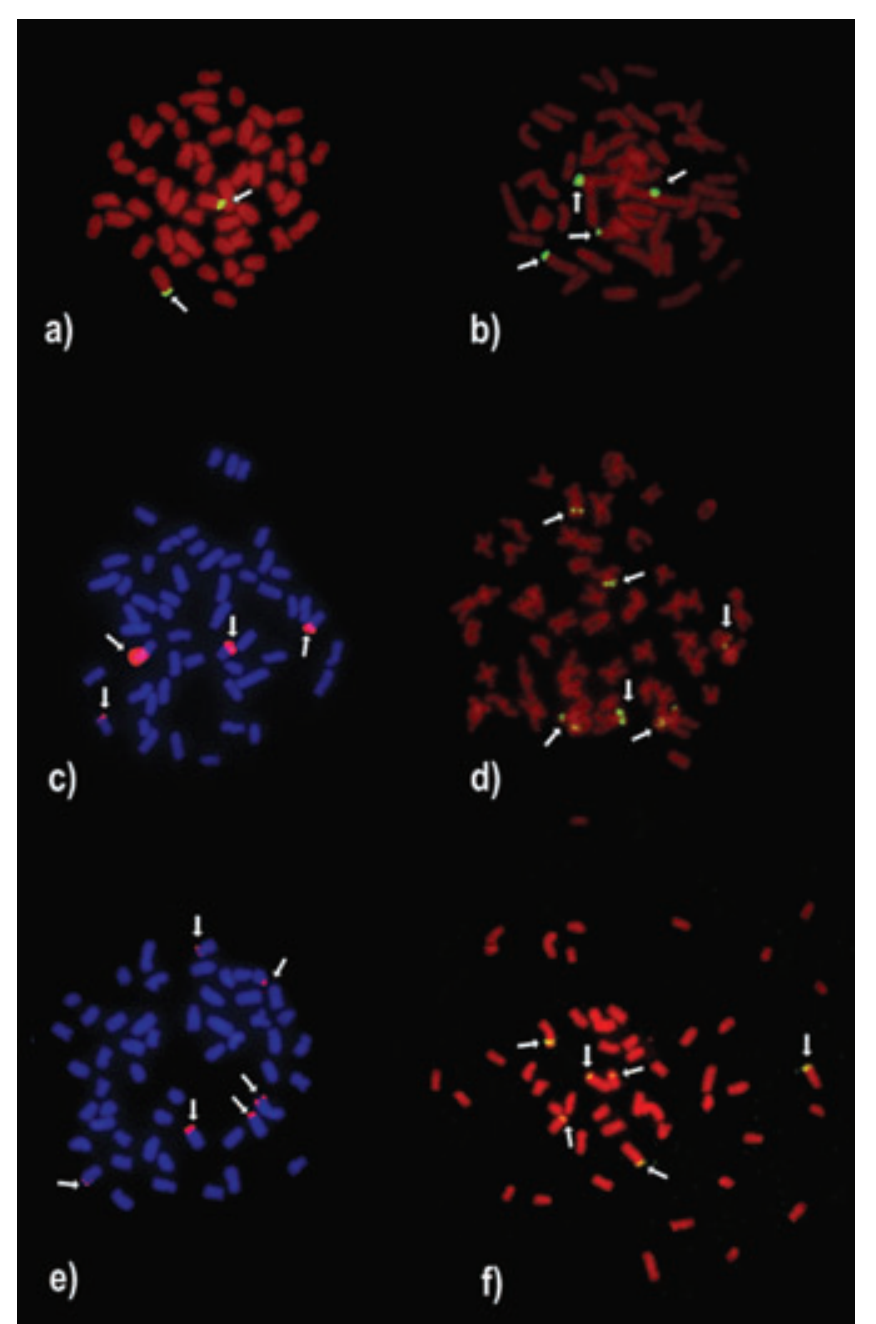

Fig. 3. Somatic metaphase of $P$. argentea are shown for the following: sample from Itatinga after in situ hybridization with the probes 18S (a) and 5S (b); sample from Botucatu after in situ hybridization with the probes 18S (c) and 5S (d); and sample from Bauru after in situ hybridization with the probes $18 \mathrm{~S}$ (e) and 5S (f). Somatic metaphase of P. anhembi after in situ hybridization with the 18S rDNA probe (g) and 5S (h) are shown. identified (Fig. 5a) (Fig. 3e). The 5S rDNA probe revealed six sites carrying the gene located in the terminal regions of the chromosomes (Fig. 3f). Conspicuous heterochromatic blocks were found in the centromeric regions in almost all of the chromosomes. Heterochromatin was located in the whole small arm of chromosomes 15 and 16 in the terminal region of chromosomes number 3, 6, 17, 20 and 22 (Fig. 5b).

The 13 specimens of $P$. anhembi (4 females and 9 males) analyzed with conventional Giemsa staining showed a diploid number of $2 n=52$ chromosomes $(8 m+10 s m+16 s t+18 a)$ and a fundamental number of 86 (Table 1 and Fig. 6a). Heteromorphic chromosomes were not identified in the karyotypes of males or females. Silver marks on the terminal region of the short arms of one chromosome pair, pair 21, were identified by Ag-NORs technique. A size polymorphism in the NORs was observed, mainly in pair 21 (Fig. 6a). Fluorescent in situ hybridization using the 18S DNA probe marked only two chromosomes, pair 21 (Fig. 3g). These chromosomes were also marked by the $5 \mathrm{~S}$ rDNA probe (Fig. $3 \mathrm{~h}$ ), which demonstrates the synteny of the $18 \mathrm{~S}$ and $5 \mathrm{~S}$ rDNA regions. C-banding revealed that sharp heterochromatic blocks are located in the centromeric region of multiple chromosomes and are also located interstitially in the pericentromeric and terminal regions of some chromosomes within the karotype (Fig. 6b).

\section{Molecular analysis}

A partial sequence of the COI gene ( 648 bp) and the whole sequence of the CytB gene ( $\sim 118$ bp) were obtained from 11 specimens of $P$. argentea from the three samples analyzed and from four specimens of P. anhembi. The total sequence length obtained was 1766 nucleotides, and no insertions, deletions or stop-codons were identified.

The neighbor-joining tree of the K2P genetic distance show that cluster formations coincide with the four samples analyzed. Three clusters represent the $P$. argentea samples and one cluster represents the $P$. anhembi sample (Fig. 7). The genetic distance between clusters of $P$. argentea ranged from 2.8\% (Botucatu x Itatinga) to $4.6 \%$ (Botucatu x Bauru) (Table 2). The variation within each cluster ranged from 0 (Botucatu) to $0.2 \%$ (Itatinga) (Table 2). The genetic distance (K2P) found between the $P$. anhembi cluster and the clusters of $P$. argentea ranged from $2.4 \%$ (P. anhembi x Itatinga) to 4.5\% (P. anhembi x Bauru).

\section{Discussion}

A diploid number of 52 chromosomes was observed in all specimens of $P$. argentea and $P$. anhembi analyzed in this study. The same chromosome number was observed by Portela et al. (1988) and Peres et al. $(2007,2008)$ in their analysis of $P$. argentea, which suggests that there is a conserved diploid number for this genus. The same chromosome number is also observed in other fish species belonging to the subfamily Stevardiinae (Oliveira et al., 2005), which includes the genus Bryconamericus (Eigenmann, 1907) and Mimagoniates (Regan, 1907). 
The various karyotypic formula and fundamental numbers found in the samples of $P$. argentea and P. anhembi analyzed indicate that extensive rearrangements are occurring in the chromosomes, e.g., paracentric inversions that alter the karyotypic formula without causing changes in the diploid number. Stable differences in the karyotypes indicate that the different samples of $P$. argentea analyzed are reproductively isolated, which favors the establishment of the observed changes.
The nucleolus organizer regions detected by the Ag-NORs technique have been extensively studied in fish and are considered good cytogenetic markers, which support taxonomic studies (Galetti , 1998). In the samples of P. argentea and P. anhembi studied, simple (Itatinga, Botucatu and $P$. anhembi) and multiple (Bauru) NORs were detected (Fig. 5a) in chromosomes with different morphologies. These findings may be due to active chromosome modifications (Gromicho \& Collares-Pereira, 2004), chromosomal translocation or to their association with

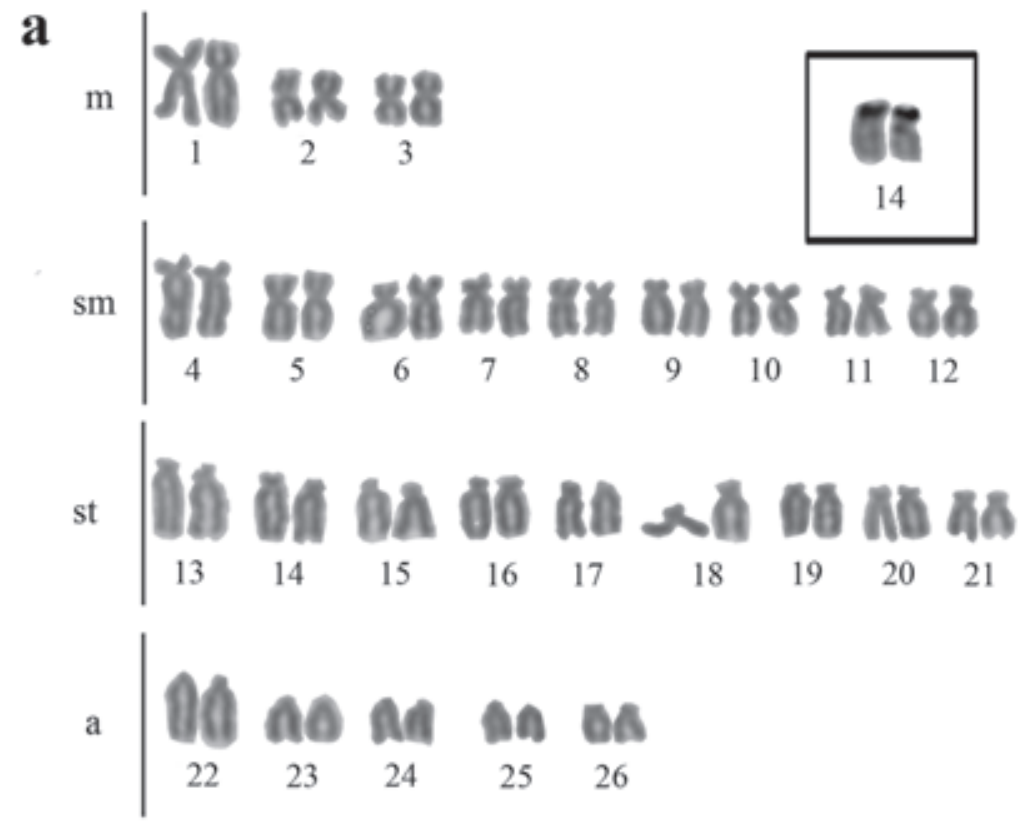

b
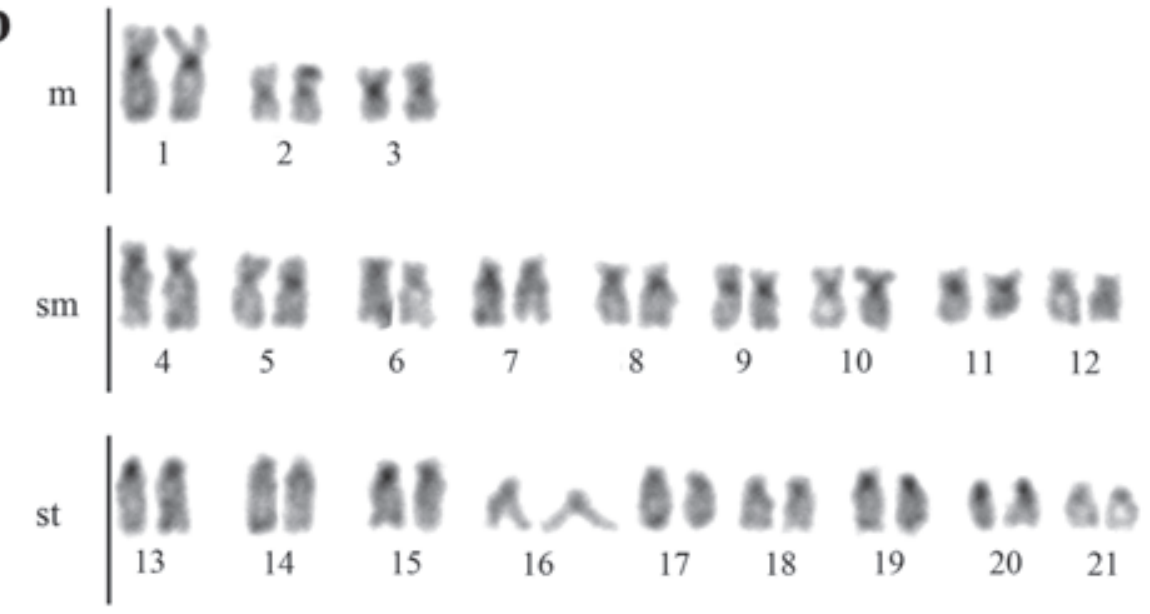

a

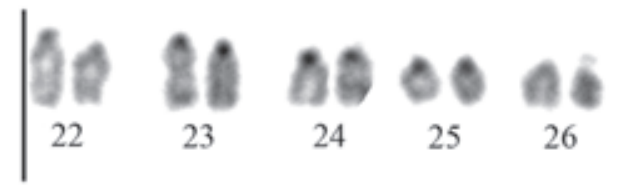

Fig. 4. Karyotype of P. argentea from Botucatu, after Giemsa staining (a) and C-banding (b) are shown. In detail, the NORbearing chromosomes are shown. Bar $=10 \mu \mathrm{m}$. 
transposable elements that carry rDNA sequences and disperse them along the genome. The polymorphism of the NORs is a relatively common event in Neotropical fish (e.g. Foresti et al., 1981; Brum et al.; 1998; Vicari et al., 2006).

Multiple sites of $18 \mathrm{~S}$ rDNA were found in the sample of $P$. argentea collected in the São Francisco River Basin and analyzed by Peres et al. (2008). Similar sites were also found in the population of $P$. argentea from the Bauru sample analyzed in the present work (Fig. 3e). In the samples of $P$. anhembi and $P$. argentea from Itatinga two 18S rRNA gene sites were detected and sample from Botucatu four 18S rRNA gene sites were observed (Fig. 3). In situ hybridization (FISH) using the $18 \mathrm{~S}$ rDNA probe confirmed the data obtained by silver nitrate impregnation into the sample of $P$. argentea from Itatinga and the population of $P$. anhembi (Fig. 3). However, FISH revealed six chromosome sites in individuals from Bauru, two marks more than the number visualized by Ag-NORs (Figs. 3 and 5, respectively). Four markers were visualized by FISH in the sample from Botucatu, which is two more than the observed number by silver nitrate incorporation (Figs. 3 and 4). The differences in marking by these techniques may reflect the activity of the NORs during the previous interphase (Roussel et al., 1996; Zurita et al., 1997; Gromicho \& Collares-Pereira, 2004).

Silver has an affinity for some proteins associated with NORs and not with rDNA, which may produce false results depending on the activity of the ribosomal gene. The use of in situ hybridization should reveal a more accurate number of rDNA sites present in the genome. Recently, it has been suggested that filamentous fungi are capable of multiplying and integrating rDNA sites into other areas of the genome through a process of retrotransposition (Rooney \& Ward, 2005). The intra and interspecific variation in the rDNA site locations
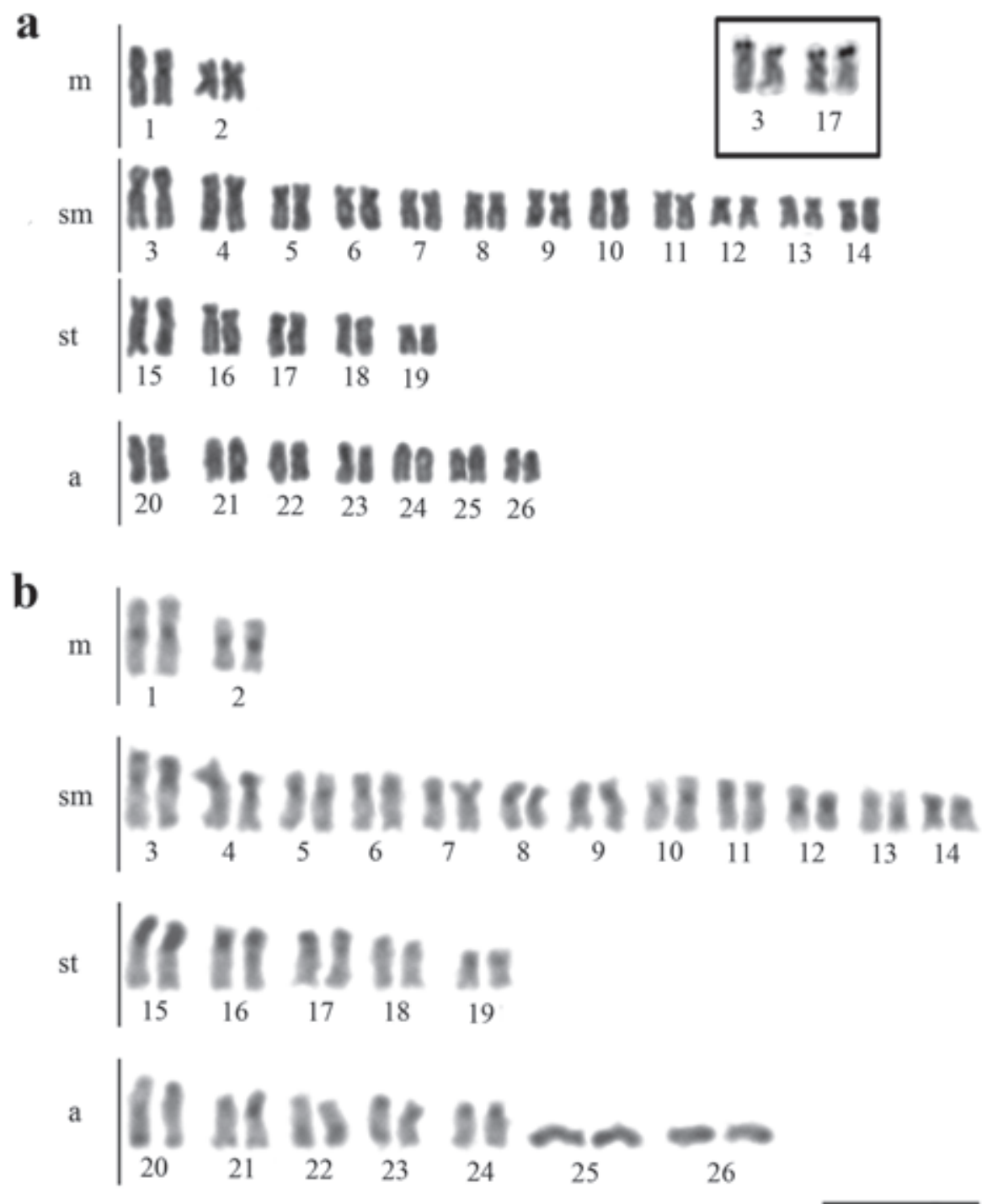

Fig. 5. Karyotype of P. argentea from Bauru, after Giemsa staining (a) and C-banding (b) are shown. In detail, the NOR-bearing chromosomes are shown. Bar $=10 \mu \mathrm{m}$. 
observed in grasshoppers may be the result of the transposition of a few rRNA genes to new chromosome locations. After their amplification, and in case of the elimination of the original NOR, the new site could substitute for the original site in function. The inactive rDNA loci observed may correspond to those sites that are in the process of being eliminated, and the cryptic NORs may correspond to a few rDNA units that have been moved but not yet amplified (Cabrero \& Camacho, 2008).

The next step should be to determine if rDNA is present in these cryptic NORs and to investigate whether they are associated with transposable elements that move along with them through genomes. In species showing interpopulation variation in rDNA location, such as Eyprepocnemis plorans (Charpentier, 1825), a spread of rDNA throughout the genome seems to have recently taken place (Cabrero et al., 2003). Guillén et al. (2004) worked with humans and chimpanzees and suggested that the elimination of rDNA or gene silencing by methylation is caused by the presence of heterochromatin, which is involved in different mechanisms that inactivate
NORs. Cabrero \& Camacho (2008) proposed that the NORs may correspond to hidden springs, i.e., a gene with a few copies of rRNA that moved to a new location, and the inactive rDNA loci could be in the process of being eliminated. Many hidden loci could occur with the incorporation of rRNA genes into new chromosome locations, and its expansion would give rise to new NORs (Singh et al., 2009).

The 5 rDNA clusters have been identified in two pairs of chromosomes of P. argentea by Peres et al. (2008), and this finding is consistent with the data obtained for the P. argentea sample from Itatinga (Fig. 3b). However, in P. argentea individuals from the Botucatu and Bauru samples six chromosomes were found to carry the genes (Fig. 3d and 3f), and in P. anhembi only one chromosome pair contained 5S rDNA clusters. This variation in the number of chromosomes carrying $5 \mathrm{~S}$ rDNA may be due to an association between these regions and transposons, which are responsible for scattering rDNA regions in the genome of eukaryotes (Drouin \& Moniz de Sá, 1995). The variations found in this region have been a

a

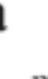

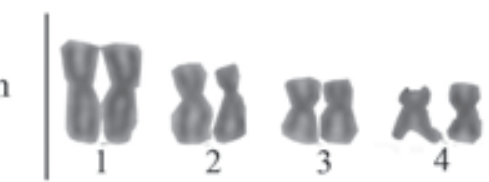

sm
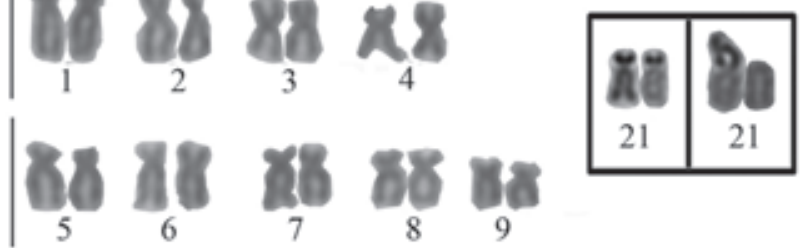

st
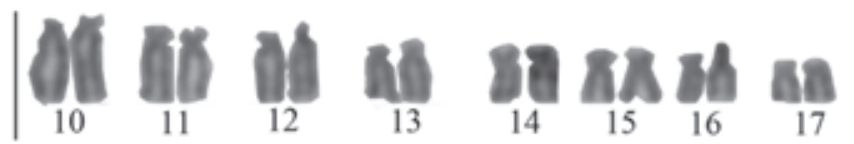

a
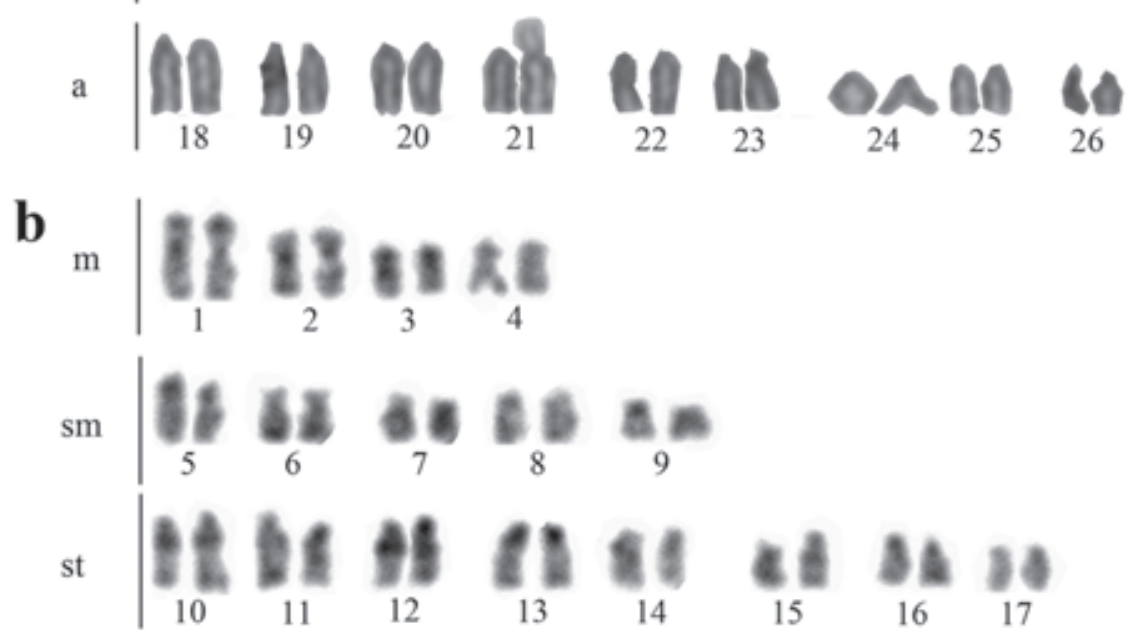

a
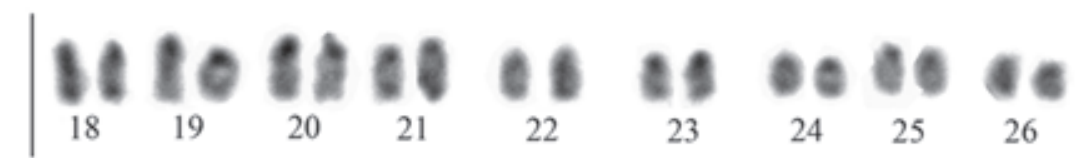

Fig. 6. Karyotype of P. anhembi from Salesópolis, after Giemsa staining (a) and C-banding (b) are shown. In detail, the NORbearing chromosomes are shown. Bar $=10 \mu \mathrm{m}$. 


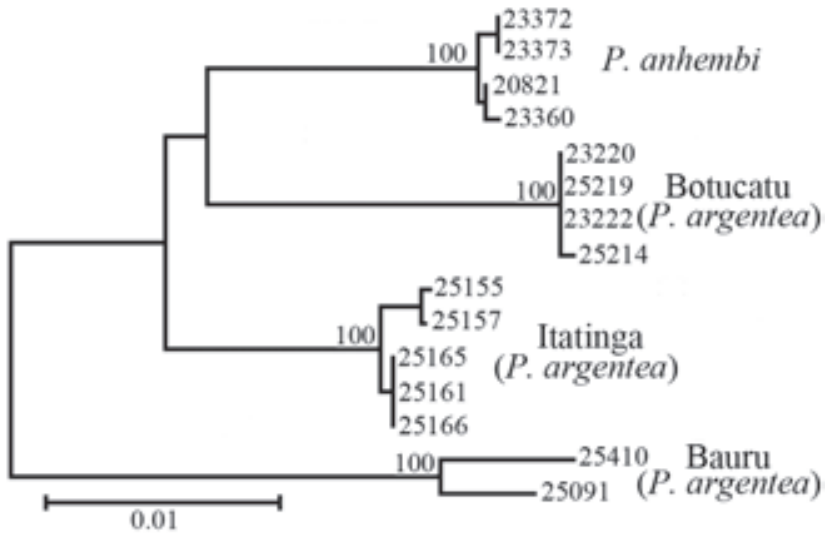

Fig. 7. Neighbor-joining cladogram constructed from the partial sequences of genes $\mathrm{COI}$ and $\mathrm{CytB}$ in the species $P$. argentea and P. anhembi are shown. Bootstrap with 1000 replicates.

very useful tool for identifying different populations, as demonstrated in studies on the genus Astyanax (Baird \& Girard, 1854) (Ferro et al., 2001; Almeida-Toledo et al., 2002; Mantovani et al., 2005; Vicari et al., 2008). The location of the 5S rDNA region in chromosomes is described for more than 60 species belonging to seven fish orders. These studies have revealed interesting information about the organization and structure of the 5S rDNA sequences present in fish chromosomes (Martins \& Wasko, 2004). In many vertebrates the 5S rDNA gene is located in only one chromosome pair (Suzuki et al., 1996; Mäkinem et al., 1997). Even the mapping of the 5S rDNA sites in fish has demonstrated that sites are frequently located at a single chromosome locus, which may correspond to an ancestral condition in this group (Martins \& Galetti, 1999). In amphibians (Schmid et al., 1987; Lucchini et al., 1993) and fishes (Mazzei et al., 2004; Nirchio \& Oliveira, 2006) the 5S rDNA genes can be located in one or more chromosomes. Variations in the 5S rDNA gene location may occur due to the presence of pseudogenes, insertions, deletions and repetitions, which have often been characterized in various organisms (Suzuki et al., 1996; Sadjak et al., 1998; Alves-Costa et al., 2006).

The occurrence of $18 \mathrm{~S}$ and 5S ribosomal DNA sites in synteny is rare in vertebrates and has only been reported in a few organisms, such as the fish species Salmo salar (Linnaeus, 1758) (Pendás et al., 1994), Oncorhynchus mykiss (Walbaum, 1792) (Moran et al., 1996), Prochilodus argenteus (Hatanaka \& Galetti, 2004), Prochilodus lineatus (Valenciennes, 1836) (Jesus et al., 2003; Vicari et al., 2006), five species of the genus Astyanax (Almeida-Toledo et al., 2002) and amphibians (Lucchini et al., 1993). Moreover, the loci have been mapped on different chromosomes in several fish species (Morán et al., 1996; Wasko et al., 2001), a condition often found in vertebrates (Lucchini et al., 1993; Suzuki et al., 1996). Our data show that in $P$. anhembi the 5 S ribosomal site is syntenic with the 18S rDNA site, which is located subterminally on the short arm of the chromosome pair 21 (Fig. 3). The synteny occurrence
Table 2. Table of genetic distance (K2P) to COI and CytB genes in one population of Piabina anhembi and three populations of $P$. argentea (Bauru, Itatinga and Botucatu) analyzed.

\begin{tabular}{lcccc}
\hline & Bauru & Itatinga & Piabina anhembi & Botucatu \\
\hline Bauru & 0.001 & & & \\
Itatinga & 0.040 & 0.002 & & \\
Piabina anhembi & 0.045 & 0.024 & 0.001 & \\
Botucatu & 0.046 & 0.028 & 0.027 & 0.000 \\
\hline
\end{tabular}

of these genes may be due to a risk of sequence loss in these regions by chromosomal deletions during the moving process to other chromosome sites (Hatanaka \& Galetti, 2004).

Previous studies using the C-banding technique (BSG technique) have shown that some species of fish (Gold et al., 1990), as well as other animals and plants (Sumner, 1990), have heterochromatic bands in different quantities, which are mainly distributed in the centromeric or telomeric regions of chromosomes and less frequently in interstitial regions (Weiler \& Wakimoto, 1995; Oliveira \& Wright, 1998). All of the $P$. argentea samples analyzed contained heterochromatic blocks in the centromeric region of almost all of the chromosomes and in the terminal regions of some of the chromosomes. P. argentea specimens from Itatinga are partially heterochromatic in the short arm of chromosome pair 4 (Fig. 2b). In individuals from the Botucatu sample the short arms of chromosome pairs 13 and 15 are partially heterochromatic. In individuals from the Bauru sample the short arm of chromosome pairs 3, 4 and 17 are partially heterochromatic, while in chromosome pairs 15 and 16 the short arms were entirely heterochromatic. Additionally, in this sample chromosomes pairs 20 and 22 show a marked block in the terminal region of the long arm. The $P$. anhembi specimens contained bands in the interstitial region of the long arms in chromosome pairs 10 and 12 .

The differences in the distribution of heterochromatin in the karyotypes of the $P$. argentea analyzed provide strong evidence that these samples may represent different groups. The results showing that $P$. anhembi contains bands in different regions than the bands observed in P. argentea demonstrates that the pattern of heterochromatin distribution can be a useful tool in the cytogenetic studies of several Neotropical fish groups. The differences in the distribution of C-banding positive segments may be used to help characterize of genera, species and populations (Mantovani et al., 2000). Although the functional role of heterochromatin is still poorly understood, it appears that the expression of some "euchromatic" genes is dependent on both "heterochromatic" gene expression and the activation of inhibitory factors (Weiler \& Wakimoto, 1995; Oliveira \& Wright, 1998).

According to the molecular analyses, $P$. argentea could be divided into three groups that correspond to the samples analyzed. The genetic distance (K2P) between the clusters of $P$. argentea ranged from $2.8 \%$ (Botucatu $\mathrm{x}$ Itatinga) to $4.6 \%$ 
(Botucatu x Bauru) (Table 2). The variation within each cluster ranged from 0 (Botucatu) to $0.2 \%$ (Itatinga) (Table 2), and the genetic distance (K2P) between the clusters of $P$. anhembi and $P$. argentea ranged from $2.4 \%$ (P. anhembi $\mathrm{x}$ Itatinga) to $4.5 \%$ (P. anhembi $\mathrm{x}$ Bauru). These results suggest that the three groups analyzed represent distinct taxonomic units, and this finding is supported by the similar values in genetic divergence (K2P) found between the groups of $P$. argentea and $P$. anhembi (Table 2), which was used as a standard reference to separate the species.

In a recent review on the distribution of genetic divergence in the "Barcoding" data of fishes $(\mathrm{N}=1088)$, Ward (2009) showed that approximately $17 \%$ of the genetic divergence values among congener species is less than $3 \%$ and $3.7 \%$ of the congener comparisons are less than $1 \%$. The author suggests that if an unknown sample has a genetic divergence greater than $2 \%$ to a known specimen, the probability that the sample is a different species exceeds $95 \%$. Studies in species of the genus Astyanax from Mesoamerica performed by Ornelas-Garcia et al. (2008) revealed similar results. The authors suggested that the groups studied represent new species of Astyanax (Ornelas-Garcia et al., 2008). Similar results in genetic divergence inter-clusters to those found in the present work suggest that more than one species exists under the same denomination (Smith et al., 2005; Witt et al., 2006; Ward et al., 2007; Ward et al., 2008; Nguyen \& Seifert, 2008; Yassin et al., 2008).

The cytogenetic and molecular differences found in the samples of Piabina analyzed support the hypothesis proposed by Lowe Mc Connell (1999) that large tropical rivers may act as "barriers" (physical, chemical or biotic) for small fish species and contribute to their speciation because of their isolation in micro-basins. These events appear to have occurred with the $P$. anhembi that are only found in the high Tietê River basin. The separation of small groups with little to no gene flow would help to maintain the different characteristics found in the separated groups, and this type of separation could explain the cytogenetic and mitochondrial DNA differences observed in this study. Our data emphasizes the importance of combining both cytogenetic data and molecular markers in evolutionary studies. Our data also assists in the genetic identification of Piabina species. Furthermore, the use of mitochondrial genes in systematic and evolutionary studies has become important in helping to distinguish species. We conclude that the samples of $P$. argentea analyzed may represent three different biological units that have not yet been nominated and suggest isolation mechanisms that have led to the initial differentiation of these groups.

\section{Acknowledgements}

We are grateful to R. Devidé for his help with the fish collection. Financial support for this study was provided by CNPq (process 132021/2007-2) and FAPESP (process 06/ 59415-1).

\section{Literature Cited}

Almeida-Toledo, L. F., F. Foresti \& S. A. Toledo-Filho. 2000. Karyotypic evolution in Neotropical freshwater fish. Chromosome Today, 13: 169-182.

Almeida-Toledo, L. F., C. Ozouf-Costaz, F. Foresti, C. Bonilho, F. Porto-Foresti \& M. F. Z. Daniel-Silva. 2002. Conservation of the 5S-bearing chromosome pair and co-localization with major rDNA clusters in five species of Astyanax (Pisces, Characidae). Animal Cytogenetics and Genome Research, 97: 229-233.

Alves-Costa, F. A., A. P. Wasko, C. Oliveira, F. Foresti \& C. Martins. 2006. Genomic organization and evolution of the $5 S$ ribossomal DNA in Tilapiini fishes. Genetica, 127: 243-252.

Brum, M. J. I., C. F. M. L. Muratori, P. R. D. Lopes \& P. R. G. Viana. 1998. A ictiofauna do sistema lagunar de Maricá (RJ). Acta Biológica Leopoldensia, 16: 45-55.

Cabrero, J., A. Bugrov, E. Warchalowska-Sliwa, M. D. López-León, F. Perfectti \& J. P. M. Camacho. 2003. Comparative FISH analysis in five species of Eyprepocnemidine grasshoppers. Heredity, 90: 377-381.

Cabrero, J. \& J. P. Camacho. 2008. Location and expression of ribosomal RNA genes in grasshoppers: abundance of silent and cryptic loci. Chromosome Research, 16: 595-607.

Drouin, G. \& M. Moniz de Sá. 1995. The concerted evolution of 5S ribosomal genes linked to the repeat units of other multigene families. Molecular Biology Evolution, 12: 481-493.

Edgar, R. C. 2004. MUSCLE: a multiple sequence alignment method with reduced time and space complexity. BMC Bioinformatics, 5: 113.

Felsenstein, J. 1985. Confidence limits on phylogenies: an approach using the bootstrap. Evolution, 39: 783-791.

Ferro, D. A. M., D. M. Néo, O. Moreira-Filho \& L. A. C. Bertollo. 2001. Nucleolar organizing regions, $18 \mathrm{~S}$ and 5S in Astyanax scabripinnis (Pisces, Characidae): Population distribution and Functional diversity. Genetica, 110: 147-153.

Foresti, F., L. F. Almeida-Toledo \& S. A., Toledo.1981. Polymorphic nature of nucleolus organizer regions in fishes. Cytogenetics and Cell Genetics, 31: 137-144.

Galetti , P. M. 1998. Chromosome diversity in Neotropical fishes: NOR studies. Italian Journal of Zoology, 65: 53-56.

Gold, J. R., C. Y. Li, N. S. Shipley \& P. K. Powers. 1990. Improved methods for working with fish chromosomes with a review of metaphase chromosome banding. Journal Fish Biology, 37: 563-575.

Gromicho, M. \& M. J. Collares-Pereira. 2004. Polymorphism of major ribosomal gene chromosomal sites (NOR-phenotypes) in the hybridogenetic fish Squalius alburnoides complex (Cyprinidae) assessed through crossing experiments. Genetica, 122: 291-302.

Guillén, A. K., Y. Hirai, T. Tanoue \& H. Hirai. 2004. Transcriptional repression mechanisms of nucleolus organizer regions (NORs) in humans and chimpanzees. Chromosome Research, 12: 225-237.

Hatanaka, T. \& P. M. Galetti. 2004. Mapping of the $18 \mathrm{~S}$ and $5 \mathrm{~S}$ ribosomal RNA genes in the fish Prochilodus argenteus Agassiz, 1829 (Characiformes, Prochilodontidae). Genetica, 122: 239-244.

Hebert, P. D. N., A. Cywinska, S. L. Ball \& J. R. deWaard. 2003. Biological identifications through DNA barcodes. Proceedins of the Royal Society London Biological, 270: 313-321.

Howell, W. M. \& D. A. Black.1980. Controlled silver-staining of nucleolus organizer regions with a protective colloidal developer: a 1- step method. Experimentia, 36: 1014-1015. 
Kimura, M. 1980. A simple method for estimating evolutionary rate of base substitutions through comparative studies of nucleotide sequences. Journal of Molecular Evolution, 16: 111-120.

Jesus, C. M., P. M. Galetti, S. R. Valentini \& O. Moreira-Filho. 2003. Molecular characterization and chromosomal localization of two families of satellite DNA in Prochilodus lineatus (Pisces, Prochilodontidae), a species with B chromosomes. Genetica, 118: 25-32.

Lara, A., J. L. Ponce de Leon, R. Rodriguez, D. Casane, G. Cote, L. Bernatchez \& E. Garcia-Machado. 2010. DNA barcoding of Cuban freshwater fishes: evidence for cryptic species and taxonomic conflicts. Molecular Ecology Resources, 10: 421430.

Levan, A., K. Fredga \& A. A. Sandberg. 1964. Nomenclature for centromeric position of chromosomes. Hereditas, 52: 201-220.

Lowe Mc Connell, R. H. 1999. Estudo Ecológico de comunidades de peixes tropicais, São Paulo, Editora da Universidade de São Paulo, 534p.

Lucchini, S., I. Nardi, G. Barsacchi, R. Batistoni \& F. Andronico. 1993. Molecular cytogenetics of the ribosomal $(18 S+28 S$ and 5S) DNA loci in primitive and advanced urodele amphibians. Genome, 36: 762-773.

Mäkinem, A., C. Zijlstra, N. A. De Haan, C. H. M. Mellink \& A. A. Bosma. 1997. Localization of $18 \mathrm{~S}$ plus $28 \mathrm{~S}$ and 5 S ribosomal RNA genes in the dog by fluorescence in situ hybridization. Cytogenetics and Cell Genetics, 78: 231-235.

Mantovani, M., L. D. S. Abel, C. A. Mestriner \& O. MoreiraFilho. 2000. Accentuated polimorphism of heterocromatinand nuclear organizer regions in Astyanax scabripinnis (Pisces, Characidae): tools for understanding karyotype evolution. Genetica, 109: 161-168.

Mantovani, M., L. D. S. Abel \& O. Moreira-Filho. 2005. Conserved $5 \mathrm{~S}$ e variable $45 \mathrm{~S}$ rDNA chromosomal localization revelead by FISH in Astyanax scabripinnis (Pisces, Characidae). Genetica, 123: 211-216.

Martins, C. \& P. M. Galetti. 1999. Chromosomal localization of 5S rDNA genes in Leporinus fish (Anostomidae, Characiformes). Chromosome Research, 7: 363-367.

Martins, C. \& A. P. Wasko. 2004. Organization and evolution of 5s ribosomal DNA in the fish genome. Pp. 289-318. In: Willians, C. R. (Ed.), Focus on Genome Research. Hauppauge, NY, USA, Nova Science Publishers, 424p.

Mazzei, F., L. Ghigliotti, C. Bonillo, J. P. Coutanceau, C. OzoufCostaz \& E. Pisano. 2004. Chromosomal patterns of major 5S ribosomal DNA in six icefish species (Perciformes, Notothenioidei, Channichthyidae). Polar Biology, 28: 47-55.

Morán, P., J. L. Martínez, E. Garcia-Vásquez \& A. M. Pendás. 1996. Sex linkage of 5S rDNA in rainbow trout (Oncorhynchus mykiss). Cytogenetics and Cell Genetics, 75: 145-150

Nguyen, H. D. T. \& K. A. Seifert. 2008. Description and DNA barcoding of three new species of Leohumicola from South Africa and the United States. Personia, 21: 57-98.

Nirchio, M., \& C. Oliveira. 2006. Citogenetica de Peces. Universidad de Oriente, Venezuela, 216p.

Oliveira, C., L. F. Almeida-Toledo, F. Foresti, H. A. Britski \& S. A. Toledo-Filho. 1988 Chromosome formulae of Neotropical freshwater fishes. Revista Brasileira de Genética, 11: 577-624.

Oliveira, C., L. Almeida-Toledo \& F. Foresti. 2005. Karyotypic evolution in Neotropical fishes. Pp. 1-49. In: Pisano, E., C. Ozouf-Costaz, F. Foresti \& B. G. Kapoor (Eds.). Fish Cytogenetics. Enfild Science Publisher Inc., 518p
Oliveira, C., F. Foresti \& A.W.S. Hilsdorf. 2009. Genetics of neotropical fish: from chromosomes to populations. Fish Physiology Biochemistry, 35: 81-100.

Oliveira, C. \& J. M. Wright. 1998. Molecular cytogenetic analysis of heterochromatin in the chromosomes of tilapia, Oreochromis niloticus (Teleostei: Cichlidae). Chromosome Research, 6: 11-205.

Ornelas-Garcia, C.P., O. Dominguez-Dominguez \& I. Doadrio. 2008. Evolutionary history of the fish genus Astyanax Baird \& Girard (1854) (Actynopterigii, Characidae) in Mesoamerica reveals multiple morphological homoplasies. BMC Evolutionary Biology, 8: 340.

Pansonato-Alves, J. C., M. R. Vicari, C. Oliveira \& F. Foresti. 2011. Chromosomal diversification in populations of Characidium cf. gomesi (Teleostei: Crenuchidae). Journal of Fish Biology, 78: 183-194.

Pendás, A. M., P. Móran, J. P. Freije \& E. Garcia-Vásquez. 1994. Chromosomal location and nucleotide sequence of two tanden repeats of the Atlantic salmon 5S rDNA. Cytogenetics and Cell Genetics, 67: 31-36.

Pereira, L. H. G., G. M. G. Maia, R. Hanner, F. Foresti \& C. Oliveira. 2011. DNA barcodes discriminates freshwater fishes from the Paraíba do Sul river basin, São Paulo, Brazil. Mitochondrial DNA, 21: 1-9.

Peres, W. A. M., L. A. C. Bertollo \& O. Moreira-Filho. 2007. Comparative cytogenetics between three Characidae fish species from the São Francisco River basin. Caryologia, 60: 64-68.

Peres, W. A. M., L. A. C. Bertollo \& O. Moreira-Filho. 2008. Physical mapping of the $18 \mathrm{~S}$ and 5 s ribosomal genes in nine Characidae species (Teleostei, Characiformes). Genetics and Molecular Biology, 1: 222-226.

Pinkel, D., T. Straume \& J. W. Gray. 1986, Cytogenetic analysis using quantitative, high sensitivity, fluorescence hybridization. Proceedings of the National Academy of Sciences of the United Estates of America, 83: 2934-2938.

Portela, A. L. B. S., P. M. Galetti \& L. A. C. Bertollo. 1988. Considerations on the Chromosome Evolution of Tetragonopterinae (Pisces, Characidae). Revista Brasileira de Genética, 11: 307-316.

Reis, R. E., S. O. kullander, \& C. Ferraris. 2003. Check List of freshwater Fishes of South and Central America, Porto Alegre, Edipucrs, 729p.

Rooney, A. P. \& T. J. Ward. 2005. Evolution of a large ribosomal RNA multigene family in filamentous fungi: Birth and death of a concerted evolution paradigm. Proceedings of the National Academy of Sciences of the United Estates of America, 102: 5084-5089.

Roussel, P., C. André, L. Comai \& D. Hernandez-Verdun. 1996. The rDNA transcription machinery is assembled during mitosis in active NORs and absent in inactive NORs. The Journal of Cell Biology, 133: 235-246.

Sajdak, S. L., K. M. Reed \& R. B. Phillips. 1998. Intraindividual and interspecies variation in the 5S rDNA of coregonid fish. Journal of Molecular Evolution, 46: 680-688.

Schaefer, S. A. 1998. Conflict and resolution impact of new taxa on philogenetic studies of Neotropical cascudinhos (Siluroidea: Loricariidae). Pp. 375-400. In: Malabarba, L. R., R. E. Reis, R. P. Vari, Z. M. Lucena \& C. A. S. Lucena (Eds.). Phylogeny and classification of Neotropical fishes. Porto Alegre, EDIPUCRS, 603p.

Schmid, M., L. Vitelli \& R. Batistoni. 1987. Chromosome banding in Amphibia. XI. Constitutive heterochromatin, nucleolus organizers, 18S+28S and 5S ribosomal RNA genes in Ascaphidae, Pipidae, Discoglossidae and Pelobatidae. Chromosoma, 95: 271-284. 
Singh, M., R. Kumar, N. S. Nagpure, B. Kushwaha, I. Gond \& W. S. Lakra. 2009. Chromosomal localization of 18 S and 5S rDNA using FISH in the genus Tor (Pisces, Cyprinidae). Genetica, 137: 245-252.

Smith, M. A., N. E. Woodley, D. H. Janzen, W. Hallwachs \& P. D. N. Hebert. 2005. DNA barcodes reveal cryptic host-specificity within the presumed polyphagus members of a genus of parasitoid flies (Diptera: Tachinidae). Proceedings of the National Academy of Sciences of the United Estates of America, 103: 3657-3662.

Sumner, A. T. 1972. A simple technique for demonstrating centromeric heterochromatin. Experimental Cell Research, 75: 304-306.

Sumner, A. T. 1990. Chromosome Banding, London, Academic Division of Unwin Hyman, 434p.

Suzuki, H., S. Sakurai \& Y. Matsuda. 1996. Rat 5S rDNA spacer sequences and chromosomal assignment of the genes to the extreme terminal region of chromosome 19. Cytogenetics and Cell Genetics, 72: 1-4.

Tamura, K., J. Dudley, M. Nei \& S. Kumar. 2007. MEGA 4: Molecular Evolutionary Genetics Analysis (MEGA) Software Version 4.0. Molecular Biology Evolution, 24: 1596-1599.

Turner, B. J., N. Diffoot \& E. M. Rasch. 1992. The callichthyid catfish Corydoras aeneus is an unresolved diploid-tetraploid sibling complex. Ichthyology Exploration of Freshwater, 3: 17-23.

Valdez-Moreno, M., N. V. Ivanova, M. Elías-Guitiérrez, S. Contreras-Balderas \& P. D. N. Hebert. 2009. Probing diversity in freshwater fishes from Mexico and Guatemala with DNA barcodes. Journal of Fish Biology, 74: 377-402.

Vicari, M. R., M. C. Almeida, L. A. C. Bertollo, O. Moreira-Filho \& R. F. Artoni. 2006. Cytogenetic analysis and chromosomal characteristics of the polymorphic 18S rDNA in the fish Prochilodus lineatus (Characiformes, Prochilodontidae). Genetics and Molecular Biology, 29: 621-625.

Vicari, M. R., R. F. Artoni, O. Moreira-Filho \& L. A. C. Bertollo. 2008. Colocalization of repetitive DNAs and silencing of major rRNA genes. A case report of the fish Astyanax janeiroensis. Cytogenetic and Genome Research, 122: 67-72.
Ward, R. D., T. S. Zemlak, B. H. Innes, P. R. Last \& P. D. N. Hebert. 2005. DNA barcoding Australia's fish species. Philosophical Transactions of the Royal Society Biological sciences, 360: 1847-1857.

Ward, R. D., B. H. Holmes, T. S. Zemlak \& P. J. Smith. 2007. DNA barcoding discriminates spurdogs of the genus Squalus. Pp. 117130. In: Last, P. R., W. T. White \& J. J. Pogonoski (Eds). Descriptions of new dogfishies of the genus Squalus (Squaloidea: Squalidae). Australia, CSIRO Marine and Atmospheric Research, 130p.

Ward, R. D., B. H. Holmes \& G. K. Yearsley. 2008. DNA barcoding reveals a likely second species of Asian sea bass (barramundi) (Lates calcarifer). Journal of Fish Biology, 72: 458-463.

Ward, R. D. 2009. DNA barcode divergence among species and genera of birds and fishes. Molecular Ecology Resources, 9: 1077-1085.

Wasko, A. P., C. Martins, J. M. Wright \& P. M. Galetti. 2001. Molecular organization of 5S rDNA in fishes of the genus Brycon. Genome, 44:893-908.

Weiler, K. S. \& B. T. Wakimoto. 1995. Heterochromatin and gene expression in Drosophila. Annual Review of Genetics, 29: 577-605.

Witt, J. D. S., D. L. Threloff \& P. D. N. Hebert. 2006. DNA barcoding reveals extraordinary cryptic diversity in an amphipode genus: implications for desert spring conservation. Molecular Ecology, 15: 3073-3082.

Yassin, A., P. Capy, L. Madi-Ravazzi, D. Ogereau \& J. R. David. 2008. DNA barcode discovers two cryptic species and two geographical radiations in the invasive drosophilid Zaprionus indianus. Molecular Ecology Resources, 8: 491-501.

Zurita, F., A. Sánchez, M. Burgos, R. Jiménez \& R. Díaz de la Guardia. 1997. Interchromosomal, intercellular and interindividual variability of NORs studied with silver staining and in situ hybridization. Heredity, 78: 229-234.

Submitted November 2, 2011 Accepted March 21, 2012 Published June 29, 2012 